\title{
The role of mitochondrial DNA to determine the origin of domestic chicken
}

\author{
P. DI LORENZO ${ }^{1}$, S. CECCOBELLI ${ }^{1}$, F. PANELLA ${ }^{1}$, G. ATTARD ${ }^{2}$ and \\ E. LASAGNA ${ }^{1 *}$
}

${ }^{1}$ Dipartimento di Scienze Agrarie, Alimentari e Ambientali, Università degli Studi di Perugia, Italy; ${ }^{2}$ Institute of Earth Systems, University of Malta, Malta *Corresponding author: emiliano.lasagna@unipg.it

Mitochondrial DNA (mtDNA) is has recently lost relevance especially when utilised to study species that are characterised with a history of several migrations. Nonetheless, mtDNA can still represents a useful additional tool in the study of molecular genetic diversity. The reason for the adoption of mtDNA is that it is easy to amplify because it appears in multiple copies in the cells and the mitochondrial gene content is strongly conserved across generations. Thousands of published studies have reached conclusions about population history, patterns of gene flow, genetic structure, and species limits, on the basis of mtDNA sequence variation. MtDNA has been used to study phylo-geographic structure of avian species, and to identify the number of maternal lineages and their geographic origins. Most studies of chicken mtDNA rely on sequences of partial control region but recent researches used the complete mtDNA genome to reconstruct the history of animal domestication. The first genetic study on mtDNA suggests that the Indochinese Red Junglefowl subspecies Gallus gallus gallus is the primary ancestor of the domestic chicken (Gallus gallus domesticus). Other studies showed that at least three subspecies of Gallus gallus were enrolled in the origin of domestic chicken breeds, and that there may be at least two domestication centres: one in Southeast Asia and one in the Indian subcontinent. The authors suggested nine highly divergent clades (named clade $A-I$ ) related to geographical distribution in a wide range of domestic chickens and Red Junglefowls across Eurasian regions. Understanding when chickens were transported out of domestication centres and the directions in which they were moved provides information about prehistoric human migration, trade routes and cultural diffusion. MtDNA has been used to infer regions of domestication and to identify the number of maternal lineages and their geographic origins in macroevolution studies.

Keywords: molecular markers; maternal lineage; phylogeographic structure; animal domestication 


\section{Introduction}

The chicken has a long history of anthropomorphic usage in Southeast and East Asia, where it has been bred for entertainment and show (Macdonald and Blench, 2000). The origin and domestication of chickens has been of interest to people since at least Roman times (Storey et al., 2012). Based on archaeological and historical evidence the domestication of the fowl is thought to have occurred in multiple, independent centres. Archaeological research has identified centres of chicken domestication in India and China; both within the natural range of wild Junglefowl (Crawford, 1990).

Chickens were likely domesticated from wild Red Junglefowl, though some have suggested possible genetic contributions from other Junglefowl species (Eriksson et al., 2008; Nishibori et al., 2005). Darwin (1896) was the first to propose that all domestic fowls descended directly from one common ancestor; the Gallus Bankiva, or wild Junglefowl breed that originated in Eastern and Southern Asia. He came to this conclusion based on comparisons of morphology and progeny produced from crosses between various species of Gallus. The genus Gallus consists of four species, Red Junglefowl, Grey Junglefowl (Gallus sonnerati), Green Junglefowl (Gallus varius), and Ceylon Junglefowl (Gallus lafayetii) (Delacour, 1977; Sibley and Ahlquist, 1990; Johnsgard, 1999). Based on the morphological differences and geographical distributions, the Red Junglefowl is further subdivided into five subspecies, Gallus gallus gallus (Red Junglefowl gal), Gallus gallus spadicus (Red Junglefowl spa), Gallus gallus banchiva (Red Junglefowl ban), Gallus gallus jabouillei (Red Junglefowl jab), and Gallus gallus murgi (Red Junglefowl mur) (Johnsgard, 1999). Zoologists at the time of Darwin had reservations on giving consensus to the opinion that all our domestic chicken breeds owe their origin to the genus Gallus Bankiva; nonetheless it was acknowledged that a great majority of breeds known at the time are its descendants. With the advent of molecular biology techniques, DNA sequence-based phylogenetic analyses have been conducted. The most extensive of these DNA-based analyses examined the D-Loop region mitochondrial, and provided support for Darwin's conclusion that the chicken was established through domestication of Red Junglefowl (Fumihito et al., 1996). This conclusion was supported by other studies using microsatellites DNA (Hillel et al., 2003) and a large number of D-loop sequences (Liu et al., 2006). Recently, the analysis of the entire mtDNA genome has demonstrated that domestic chickens and wild Junglefowl may have substantial gene flow and genetic admixture following the domestication. In other case, some domestic chickens might have become feral with their descendants living as wild fowl (Miao et al., 2013). The various investigative techniques described above, do not substitute each other, but rather come together as different tools that complement each other in their specific specialisations to unravel the riddle of the history of domestication.

Understanding when chickens were transported out of domestication centres and the directions in which they drifted provides information about prehistoric human migration patterns, trade routes and cultural diffusion (Thomson et al., 2014). Possible interactions may be reconstructed by mapping the presence of chickens in archaeological assemblages (Storey et al., 2008) using historical evidence (Peters, 1913; Crawford, 1984) also thought the mtDNA application (Liu et al., 2006, Miao et al., 2013).

Mitochondrial DNA is a useful marker to trace back the origin of livestock species and has been widely used to reconstruct domestication patterns (Groeneveld et al., 2010). Microsatellites (SSR) and mitochondrial DNA (mtDNA) sequences have already proved to be useful for assessing genetic variability, while single nucleotide polymorphisms (SNPs) are becoming more and more popular due to their very density and availability of high throughput genotyping techniques. A combination of SSR and 
mtDNA markers is a complementary approach that combines the highly polymorphic microsatellites whose high mutation rates allow for small scale resolution of more recent demographic event with mtDNA which shed light on phylogeographic events dating back further in time (Feulner et al., 2004). Microsatellites have been used to asses genetic diversity of a number of native chicken population in Africa (Leroy et al., 2012; Goraga et al., 2012; Eltanany et al., 2011), Europe (Ceccobelli et al., 2013; Wilkinson et al., 2012; Zanetti et al., 2011; Bodzsar et al., 2009) and Asia (Pham et al., 2013; Cuc et al., 2010; Berthouly et al., 2009; Ngo Thim et al., 2006). The first chicken genome sequence draft was completed in 2004 (International Chicken Consortium, 2004); its availability offers new opportunities in the evaluation of chicken genetic diversity using SNPs (Gholami et al., 2014; Granevitze et al., 2014; Siwek et al., 2013; Groenen et al., 2009; Muir et al., 2008). The inheritance of mtDNA differs from that of nuclear DNA in that it has a direct lineage to the ancestral mother. The reason for this maternal inheritance pattern is that when an egg is fertilised, the cells of the resulting embryo contain the mtDNA and cytoplasm of the egg, not of the sperm. As the embryo continues to develop all of the cells contain the cytoplasm and mtDNA of the ancestral mother. The reason for the popular adoption of mtDNA markers is that it is found in great abundance in cell cytoplasm and hence easily amplified (Galtier et al., 2009). Furthermore, across a wide range of animal species, the mitochondrial gene content is strongly conserved, has little duplication, has no intron, and has very short intergenic regions (Gissi et al., 2008). The mtDNA also has specific biological properties, i.e. its direct link to its ancestral maternal inheritance and its involvement in metabolic functions that make it an appropriate marker of molecular biodiversity. Lastly, it is worth noting that mtDNA is of little use in investigating recent loss of genetic variation and any individual-level events such as identity, individual dispersal, and mating systems. Males will carry the mtDNA of their dam, but their offspring will carry the mtDNA of their own mother, and not of their father. Thus, only daughters will pass the mtDNA on to future generations.

Numerous published studies have reached conclusions about population history, patterns of gene flow, genetic structure, and species limits, on the basis of mtDNA sequence variation (Zink and Barrowclough, 2008). MtDNA has been used to study phylo-geographic structure of avian species (Ceccobelli et al., 2013), to infer regions of domestication and to identify the number of maternal lineages and their geographic origins (FAO, 2007). The huge abundance of mtDNA makes it an excellent candidate for archaeological studies that are often old or degraded samples.

\section{Evolution of mt-DNA studies in chicken}

A large amount of research has focused on reconstructing the matrilineal history of domestic chickens using mtDNA sequence data. Chicken mtDNA sequence polymorphisms have been investigated to address the questions of maternal origin and subsequent domestication events (Silva et al., 2008). It is widely accepted that within and between populations genetic diversity is essential for effective management practices and to develop sustainable conservation strategies. Most studies of chicken mtDNA rely on sequences of partial control region (Muchadeyi et al., 2008; Razafindraibe et al., 2008) but recent researches used the complete mtDNA genome to reconstruct the history of animal domestication, such as in cattle (Achilli et al., 2008; 2009; Bonfiglio et al., 2010), pigs (Wu et al., 2007), chicken (Miao et al., 2013) and sheep (Lancioni et al., 2013). As already alluded two different hypotheses are discernible about the origin of domestic chickens. Initially, it was suggested that one sub-species of Red Junglefowl (Gallus 
gallus gallus) was the main progenitor of all domestic chickens and the centre of domestication event was in Southeast Asia (Fumihito et al., 1996). Later on, other studies revealed that chickens have also been domesticated from multiple geographic centres of origin in South and Southeast Asia, (Kanginakudru et al., 2008; Oka et al., 2007). Furthermore, interspecies introgressions have also occurred from the related Grey Junglefowl (Gallus sonnerati) and possibly from Ceylon Junglefowl (Gallus lafayeti) during the domestication process (Eriksson et al., 2008).

The first genetic study on mtDNA suggest that the Indochinese Red Junglefowl subspecies Gallus gallus gallus is the primary maternal ancestor of the domestic chicken (Gallus gallus domesticus) (Fumihito et al.,1994). Liu et al. (2006) showed that at least three subspecies of Gallus gallus were enrolled in the origin of domestic chicken breeds, but also that there may be at least two domestication centres: one in Southeast Asia and one in the Indian subcontinent. The authors suggested nine highly divergent clades (named clade A-I) related to geographical distribution in a wide range of domestic chickens and Red Junglefowls across Eurasian regions. The study, involved 834 mtDNA sequences from domestic chickens and 66 mtDNA sequences from four Red Junglefowl subspecies (mainly Gallus gallus spadiceus, Gallus gallus gallus, Gallus gallus jabouillei and Gallus gallus bankiva), and identified a total of 169 different haplotypes clustered in nine highly divergent clades, named A to I, seven of them including both wild and domestic individuals. Clade E was the most ubiquitous, dominating in Europe, Middle East and India. Clades A and E were mainly distributed in South China and Japan; C clade was found in chickens from Japan and Southeast China, while F and G clades were only found in the northern part of Southeast China. Clade D could be associated to the distribution of game birds, used for cockfighting. Clade D was the most frequent in Red Junglefowl. Clade H was found only in Red Junglefowl and clade I was mainly present in Vietnam. Similarly, Oka et al. (2007) identified seven clades (named clade A-G) in Japanese chickens of which four clades A, B, C and E are identical to Liu's clades E, A, D and B, respectively. Additional data confirmed that domestication had occurred independently in different locations of Asia including India (Kanginakudru et al., 2008). A later study concluded that clade D was also the second most frequent clade in India, after clade E. Furthermore, Eriksson et al. (2008) highlighted the hybrid origin of the domestic chicken, due to ancestral hybridisation involving the Grey Junglefowl (Gallus sonneratii). Three studies have made an attempt to address the origin of African village chickens through the analysis of partial mtDNA D-Loop sequences. Muchadeyi et al. (2008) observed two distinct haplogroups in Zimbabwe village chickens which they postulated came from Southeast Asia and the Indian subcontinent. Similarly, Razafindraibe et al. (2008) observed two haplougroups in Madagascar village chicken and speculated that one was of Indonesian and the other of African continental origin or an introgression from commercial lines. At the opposite a single haplogroup thought to be of Indian origin was observed in Nigeria village chickens by Adebambo et al. (2010), while no information is yet available for the East African region. Survey its genetic diversity and trace the history of domestication Miao et al. (2013) investigated a total of 4938 mitochondrial DNA fragments including 2843 previously published and 2095 de novo units from 2044 domestic chickens and 51 Red Junglefowl (Gallus gallus). Common haplogroups A-G were shared by domestic chickens and Red Junglefowl. Rare haplougroups H-I and W-Z were specific to domestic chickens and Red Junglefowl, respectively.

The result revealed new complexities of history in chicken's domestication because the phylogeny lineages from the Red Junglefowl were mingled with those of the domestic chickens. 


\section{Conclusions}

In conclusion, mtDNA studies provide a valuable preliminary description of the population structure and demographic history, but nuclear markers (such as microsatellite and SNPs) would provide valuable additional information to complete the analysis. Several mtDNA studies demonstrated that domestic chicken is closely related to Red Junglefowl, although genetic contributions from other Junglefowls is evident. Furthermore, the chicken mitochondrial genome provides an opportunity to study their human-mediated dispersal out of domestication centres. Future archaeological investigations and multidisciplinary research, including genetic studies, are required to unravel more details.

\section{Acknowledgments}

The authors wish to thank the referee for the valuable comments to the manuscript and the constructive suggestions.

\section{References}

ACHilli, A., Olivieri, A., PellecChia, M., UbOldi, C., COlli, L., Al-ZAHERY, N., ACCETTURO, M., PAlA, M., HOOSHIAR KASHANI, B., PEREGO, U.A., BATTAGLIA, V., FORNARINO, S., KALAMATI, J., HOUSHMAND, M., NEGRINI, R., SEMINO, O., RICHARDS, M., MACAULAY, V., FERRETTI, L., BANDELT, H.J, AJMONE-MARSAN, P. and TORRONI, A. (2008) Mitochondrial genomes of extinct aurochs survive in domestic cattle. Current Biology 18: 157-158.

ACHILli, A., Bonfiglio, S., Olivieri, A., MAluSA, A., PAlA, M., KASHANi, B.H., PEREgO, U.A., AJMONE-MARSAN, P., LIOTTA, L., SEMINO, O., BANDELT, H.J, FERRETTI, L. and TORRONI, A. (2009) The multifaceted origin of taurine cattle reflected by the mitochondrial genome. PLoS One 4: e5753.

ADEBAMBO, A.O., MOBEGI, V.A., MWACHARO, J.M., OLADEJO, B.M., ADEWALE, R.A., ILORI, L.O., MAKANJUOLA, B.O., AFOLAYAN, O., BJØRNSTAD, G., JIANLIN, H. and HANOTTE, O. (2010) Lack of Phylogeographic Structure in Nigerian Village Chickens Revealed by Mitochondrial DNA Dloop Sequence Analysis. International. Journal of. Poultry. Science 9: 503-507.

BERTHOULY, C., LEROY, G., VAN, T.N., THANH, H.H., BED'HOM, B., NGUYEN, B.T., VU, C.C., MONICAT, F., TIXIER-BOICHARD, M., VERRIER, E., MAILLARD, J. and ROGNON, X. (2009) Genetic analysis of local Vietnamese chickens provides evidence of gene flow from wild to domestic populations. BMC genetics 10: 1 .

BODZSAR, N., EDING, H., REVAY, T., HIDAS, A. and WEIGEND, S. (2009) Genetic diversity of Hungarian indigenous chicken breeds based on microsatellite markers. Animal Genetics 40: 516-523.

BONFIGLIO, S., ACHILli, A., OLIVIERI, A., NEGRINI, R., COLLI, L., LIOTTA, L., AJMONEMARSAN, P., TORRONI, A. and FERRETTI, L. (2010) The enigmatic origin of bovine mtDNA haplogroup R: sporadic interbreeding or an independent event of Bos primigenius domestication in Italy? PLoS One 5: e15760.

CECCOBELLI, S., DI LORENZO, P., LANCIONI, H., CASTELLINI, C., MONTEAGUdO IBÁÑEZ, L. V., SABbioni, A., SARTI, F.M., WEIGEND, S. and LASAGNA, E. (2013) Phylogeny, genetic relationships and population structure of five Italian local chicken breeds. Italian Journal of Animal Science 12: 410-417.

CUC, N.T.K., SIMIANER, H., EDING, H., TIEU, H.V., CUONG, V.C., WOLLNY, B.A., GROENEVELD, L.F. and WEIGEND, S. (2010) Assessing genetic diversity of Vietnamese local chicken breeds using microsatellites. Animal Genetics 41: 545-547.

CRAWFORD, R.D. (1984) Domestic fowl, in: MASON, I.L. (Ed) Evolution of domesticated animals, pp. 298311 (London: Longman).

CRAWFORD, R.D. (1990) Origin and history of poultry species. Elsevier 1-8.

DARWIN, C. (1896). The Variation of Animals and Plants under Domestication. 2nd edn. Vol. 1, D. Appleton: New York.

DELACOUR, J. (1977) The pheasants of the world. Surrey: SAIGA Publishing Co., Ltd. 
Mitochondrial DNA in domestic chicken: P. di Lorenzo et al.

ELTANANY, M., PHILIPP, U., WEIGEND, S. and DISTL, O. (2011) Genetic diversity of tem Egyptian chicken strains using 29 microsatellite markers. Animal genetics 42: 666-669.

ERIKSSON, J., LARSON, G., GUNNARSSON, U., BED'HOM, B., TIXIER-BOICHARD, M., STRÖMSTEDT, L., WRIGHT, D., JUNGERIUS, A., VEREIJKEN, A., RANDI, E., JENSEN, P. and ANDERSSON, L. (2008) Identification of the yellow skin gene reveals a hybrid origin of the domestic chicken. PLoS Genetics 4: e1000010.

FAO (2007) The State of the World's Animal Genetic Resources for Food and Agriculture.

FEULNER, P.G.D., BIELFELDT, W., ZACHOS, F.E., BRADVAROVIC, J., ECKERT, I. and HARTL, G.B. (2004) Mitochondrial DNA and microsatellite analyses of the genetic status of the presumed subspecies Cervus elaphus montanus (Carpathian red deer). Heredity 93: 299-306.

FUMIHITO, A., MIYAKE, T., SUMI, S., TAKADA, M., OHNO, S. and KONDO, N. (1994) One subspecies of the red junglefowl (Gallus gallus gallus) suffices as the matriarchic ancestor of all domestic breeds. Proceedings of the National Academy of Sciences USA 91: 12505-12509.

FUMIHITO, A., MIYAKE, T., TAKADA, M., SHINGU, R., ENDO, T., GOJOBORI, T., KONDO, N. and OHNO, S. (1996) Monophyletic origin and unique dispersal patterns of domestic fowls. Proceedings of the National Academy of Sciences USA 93: 6792-6795.

GALTIER, N., NABHOLZ, B., GLEMIN, S. and HURST, G.D.D. (2009) Mitochondrial DNA as a marker of molecular diversity: a reappraisal. Molecular Ecology 18: 4541-4550.

GHOLAMI, M., ERBE, M., GÄRKE, C., PREISINGER, R., WEIGEND, A., WEIGEND, S. and SIMIANER, H. (2014) Population Genomic Analyses Based on 1 Million SNPs in Commercial Egg Layers. PloS one 9: e94509.

GISSI, C., IANNELLI, F. and PESOLE, G. (2008) Evolution of the mitochondrial genome of Metazoa as exemplified by comparison of congeneric species. Heredity 101: 301-320.

GORAGA, Z., WEIGEND, S. and BROCKMANN, G. (2012) Genetic diversity and population structure of five Ethiopian chicken ecotypes. Animal genetics 43: 454-457.

GRANEVITZE, Z., DAVID, L., TWITO, T., WEIGEND, S., FELDMAN, M. and HILLEL, J. (2014) Phylogenetic resolution power of microsatellites and various single-nucleotide polymorphism types assessed in 10 divergent chicken populations. Animal genetics 45: 87-95.

GROENEN, M.A., WAHLBERG, P., FOGLIO, M., CHENG, H.H., MEGENS, H.J., CROOIJMANS, R. P., BESNIER, F., LATHROP, M., MUIR, W.M., WONG, G.K.S., GUT I. and ANDERSSON, L. (2009) A high-density SNP-based linkage map of the chicken genome reveals sequence features correlated with recombination rate. Genome Research 19: 510-519.

GROENEVELD, L.F., LENSTRA, J.A., EDING, H., TORO, M.A., SCHERF, B., PILLING, D., NEGRINI, R., FINLAY, E.K., JIANLIN, H., GROENEVELD, E., WEIGEND, S. and THE GLOBALDIV CONSORTIUM (2010) Genetic diversity in farm animals-a review. Animal Genetics 41: 6-31.

HILLEL, J., GROENEN, M.A., TIXIER-BOICHARD, M., KOROL, A.B., DAVID, L., KIRZHNER, V. M., BURKE, T., BARRE-DIRIE, A., CROOIJMANS, R.P.M.A., ELO, K., FELDMAN, M.W., FREIDLIN, P.J., MÄKI-TANILA, A., OORTWIJN, M., THOMSON, P., VIGNAL, A., WIMMERS, K. and WEIGEND, S. (2003) Biodiversity of 52 chicken populations assessed by microsatellite typing of DNA pools. Genetics Selection Evolution 35: 533-558.

INTERNATIONAL CHICKEN GENOME SEQUENCING CONSORTIUM. (2004) Sequence and comparative analysis of chicken genome provide unique perspectives on vertebrate evolution. Nature $\mathbf{4 3 2}$ : 695-716.

JOHNSGARD, P.A. (1999) The pheasants of the world, biology and natural history Smithsonian Institution Press, Washington, District of Columbia 432.

KANGINAKUDRU, S., METTA, M., JAKATI, R.D. and NAGARAJU, J. (2008) Genetic evidence from Indian red jungle fowl corroborates multiple domestication of modern day chicken. Evolutionary Biology $\mathbf{8}$ : 174.

lancioni, H., Di lorenzo, P., CECCOBElli, S., PEREGo, U.A, Miglio, A., LANDi, V., ANTOGNONI, M.T., SARTI, F.M., LASAGNA, E. and ACHILLI, A. (2013) Phylogenetic relationships of three Italian merino-derived sheep breeds evaluated through a complete mitogenome analysis. PLoS One 8: e73712.

LEROY, G., KAYANG, B.B., YOUSSAO, I.A., YAPI-GNAORÉ, C.V., OSEI-AMPONSAH, R., N'GORAN, E.L., FOTSA, J.C., BENABDELJELI, K., BED'HOM, B., TIXIER-BOICHARD, M. and ROGNON, X. (2012) Gene diversity, agroecological structure and introgression patterns among village chicken populations across North, West and Central Africa. BMC genetics 13: 34.

LIU, Y.P., WU, G.S., YAO, Y.G., MIAO, Y.W., LUIKART, G., BAIG, M., BEJA-PEREIRA, A., DING Z. L., GOUNDER PALANICHAMY, M. and ZHANG, Y.P. (2006) Multiple maternal origins of chickens: out of the Asian jungles. Molecular Phylogenetics and Evolution 38: 12-19.

MACDONALD, K.C. and BLENCH, R.M. (2000) Chickens, in: KIPLE, K.F. \& ORNELAS, K.C. (Eds) The Cambridge World History of Food, pp. 1: 496-499 (Cambridge University Press: Cambridge). 
MIAO, Y.W., PENG, M.S, WU, G.S., OUYANG, Y.N., YANG, Z.Y., YU, N., LIANG, J.P., PIANCHOU, G., BEJA-PEREIRA, A., MITRA, B., PALANICHAMY, M.G., BAIG, M., CHAUDHURI, T.K., SHEN, Y.Y., KONG, Q.P., MURPHY, R.W., YAO Y.G. and ZHANG, Y.P. (2013) Chicken domestication: an updated perspective based on mitochondrial genomes. Heredity 110: 277-282.

MUCHADEYI, F.C., EDING, H., SIMIANER, H., WOLLNY, C.B.A., GROENEVELD, E. and WEIGEND, S. (2008) Mitochondrial DNA D-loop sequences suggest a Southeast Asian and Indian origin of Zimbabwean village chickens. Animal Genetics 39: 615-622.

MUIR, W.M., WONG, G.K.S., ZHANG, Y., WANG, J., GROENEN, M.A., CROOIJMANS, R.P., MEGENSD, H.J., ZHANGE, H., OKIMOTOF, R., VEREIJKENG, A., JUNGERIUS, A., ALbersG, G.A.A., LAWLEYH, C.T., DELANYI, M.E., MACEACHERNE, S. and CHENGE, H. H. (2008) Genome-wide assessment of worldwide chicken SNP genetic diversity indicates significant absence of rare alleles in commercial breeds. Proceedings National Academy of Sciences 105: 17312-17317.

NISHIBORI, M., SHIMOGIRI, T., HAYASHI, T. and YASUE, H. (2005) Molecular evidence for hybridisation of species in the genus Gallus except for Gallus varius. Animal Genetics 36: 367-375.

NGO THIM, K.C., MUCHADEYI, F.C., BAULAIN, U., EDING, H., WEIGEND, S. and WOLLNY, C.B. A. (2006) An assessment of genetic diversity of Vietnamese H'mong chickens. International Journal of Poultry Science 5: 912-920.

OKA, T., INO, Y., NOMURA, K., KAWASHIMA, S., KUWAYAMA, T., HANADA, H., AMANO, T., TAKADA, M., TAKAHATA, N., HAYASHI, Y. and AKISHINONOMIYA, F. (2007) Analysis of mtDNA sequences shows Japanese native chickens have multiple origins. Animal Genetics 38: 287-293.

PHAM, M.H., BERTHOULY-SALAZAR, C., TRAN, X.H., CHANG, W.H., CROOIJMANS, R.P.M.A., LIN, D.Y., HOANG, V.T., LEE, Y.P., TIXIER-BOICHARD, M. and CHEN, C.F. (2013) Genetic diversity of Vietnamese domestic chicken populations as decision making support for conservation strategies. Animal genetics 44: 509-521.

PETERS, J.P. (1913) The cock. Journal of the American Oriental Society 33: 363-401.

RAZAFINDRAIBE, H., MOBEGI, V.A., OMMEH, S.C., RAKOTONDRAVAO, M.L., BJØRNSTAD, G., HANOTTE, O. and JIANLIN, H. (2008) Mitochondrial DNA Origin of Indigenous Malagasy Chicken. Animal Biodiversity and Emerging Diseases 1149: 77-79.

SIBLEY, C.G. and AHLQUIST, J.E. (1990) Phylogeny and classification of birds: a study in molecular evolution. Yale University Press.

SILVA, P., GUAN, X., HO-SHING, O., JONES, J., XU, J., HUI, D., NOTTER, D. and SMITH, E. (2008) Mitochondrial DNA-based analysis of genetic variation and relatedness among Sri Lankan indigenous chickens and the Ceylon Junglefowl (Gallus lafayetti). Animal Genetics 40: 1-9.

SIWEK, M., WRAGG, D., SŁAWIŃSKA, A., MALEK, M., HANOTTE, O., MWACHARO, J.M. (2013) Insights into the genetic history of Green-legged Partridgelike fowl: mtDNA and genome-wide SNP analysis. Animal genetics 44: 522-532.

STOREY, A.A., LADEFOGED, T.N. and MATISOO-SMITH, E.A. (2008) Counting Your Chickens: Density and Distribution of Chicken Remains in Archaeological Sites of Oceania. International Journal of Osteoarchaeology 18: 240-261.

STOREY, A.A., STEPHEN, A.J., BRYANT, D., CARSON, M., EMERY, K., DE FRANCE, S., HIGHAM, C., HUYNEN, L., INTOH, M., JONES, S., KIRCH, P.V., LADEFOGED, T., MCCOY, P., MORALESMUNIZ, A., QUIROZ, D., REITZ, E., ROBINS, J., WALTER, R. and MATISOO-SMITH E. (2012) Investigating the global dispersal of chickens in prehistory using ancient mitochondrial DNA signatures. PLOS ONE 7: e39171.

THOMSON, V.A., LEBRASSEUR, O., AUSTIN, J.J., HUNT, T.L., BURNEY, D.A., DENHAM, T., RAWLENCE, N.J., WOOD, J.R., GONGORA, J., FLINK, L.G., LINDERHOLM, A., DOBNEY, K., LARSON, G. and COOPER, A. (2014) Using ancient DNA to study the origins and dispersal of ancestral Polynesian chickens across the Pacific. Proceedings National Academy of Sciences 111: 4826-4831.

WILKINSON, S., WIENER, P., TEVERSON, D., HALEY, C.S. and HOCKING, P.M. (2012) Characterisation of the genetic diversity, structure and admixture of British chicken breeds. Animal genetics 43: 552-563.

WU, G.S., YAO, Y.G., QU, K.X., DING, Z.L., LI, H., PALANICHAMY, M.G., DUAN, Z.Y., LI, N., CHEN, Y.S. and ZHANG, Y.P. (2007) Population phylogenomic analysis of mitochondrial DNA in wild boars and domestic pigs revealed multiple domestication events in East Asia. Genome Biology and Evolution 8: 245

ZANETTI, E., DE MARCHI, M., ABBADI, M. and CASSANDRO, M. (2011) Variation of genetic diversity over time in local Italian chicken breeds undergoing in situ conservation. Poultry Science 90: 2195-2201.

ZINK, R.M. and BARROWCLOUGH, G.F. (2008) Mitochondrial DNA under siege in avian phylogeography. Molecular Ecology 17: 2107-2121. 
318 World's Poultry Science Journal, Vol. 71, June 2015 